\title{
Exploring the Potential of a German Living Lab Research Infrastructure for the Development of Low Resource Products and Services
}

\section{Justus von Geibler ${ }^{1, *}$, Lorenz Erdmann ${ }^{2}$, Christa Liedtke ${ }^{1,3}$, Holger Rohn ${ }^{4}$, Matthias Stabe ${ }^{5}$, Simon Berner ${ }^{2}$, Kristin Leismann ${ }^{4}$, Kathrin Schnalzer ${ }^{5}$ and Katharina Kennedy ${ }^{1}$}

1 Wuppertal Institute for Climate Environment and Energy, Döppersberg 19, Wuppertal 42103, Germany; E-Mails: christa.liedtke@wupperinst.org (C.L.); k.kennedy@hotmail.de (K.K.)

2 Fraunhofer Institute for Systems and Innovation Research ISI, Breslauer Straße 48, Karlsruhe 76139, Germany; E-Mails: lorenz.erdmann@isi.fraunhofer.de (L.E.); simon.berner@isi.fraunhofer.de (S.B.)

3 Department of Design, Folkwang University of the Arts, Klemensborn 39, Essen 45239, Germany

4 Faktor 10-Institut für nachhaltiges Wirtschaften gemeinnützige GmbH, Alte Bahnhofstraße 13, Friedberg 61169, Germany; E-Mails: holger.rohn@f10-institut.org (H.R.); kristin.leismann@f10-institut.org (K.L.)

5 Fraunhofer-Institute for Industrial Engineering IAO, Nobelstraße 12, Stuttgart 70569, Germany; E-Mails: matthias.stabe@iao.fraunhofer.de (M.S.); kathrin.schnalzer@iao.fraunhofer.de (K.S.)

* Author to whom correspondence should be addressed; E-Mail: justus.geibler@wupperinst.org; Tel.: +49-202-2492-168; Fax: +49-202-2492-138.

Received: 14 June 2013; in revised form: 22 July 2014 / Accepted: 19 August 2014 / Published: 24 September 2014

\begin{abstract}
Living Labs for Sustainable Development aim to integrate users and actors for the successful generation of low-resource innovations in production-consumption systems. This paper investigates potentials of and measures towards the realization of a German Living Lab infrastructure to support actor-integrated sustainability research and innovations in Germany. Information was primarily derived from extensive dialog with experts from the fields of innovation, sustainable development and the Living Lab community (operators, users, etc.), which was facilitated through interviews and workshops. A status quo analysis revealed that, generally, the sustainability and Living Lab communities are hardly intertwined. Twelve Living Labs that explicitly consider sustainability aspects were identified. The application fields "Living and Working", "Town, Region and Mobility", and "Retail and Gastronomy" were identified as particularly suitable for investigation in
\end{abstract}


Living Labs and highly relevant in terms of resource efficiency. Based on the analyses of drivers and barriers and SWOT, keystones for the development of a research infrastructure for user integrated development of sustainable products and services were formulated. Suggested strategies and measures include targeted funding programs for actor-integrated, socio-technical research based on a Living Lab network, a communication campaign, and programs to foster networking and the inclusion of SMEs.

Keywords: Living Lab; user integration; innovation; sustainability; resources; resource efficiency; innovation system; research infrastructure

\section{Introduction}

The worldwide consumption of resources is ever increasing [1], triggering effects such as climate change, migration, and loss of productive land [2-4]. Despite more efficient and consistent production methods, an energy- or resource turnaround is out of sight. Current lifestyles in industrialized countries and related household consumption are major basic drivers of the overconsumption of natural resources by the human technological system [5,6]. A recent study provides a reference frame of the magnitude of reduction needed in terms of resource consumption, more specifically the material footprint which represents the sum of abiotic and biotic resources as well as erosion in agriculture and forestry, calculated based on the MIPS (Material Input per Service unit) methodology [7] and including the same resource categories as TMC (total material consumption) and TMR (total material requirement) used on the macroeconomic level [8]). Based on data from Finland, a material footprint of 8 tonnes per person per year is suggested as a target for sustainable household consumption by 2050 [9]. On top of that, an additional material footprint of 2 tonnes per person per year is suggested for public consumption (public infrastructure, etc.). To achieve this target, a reduction of the present material footprint of household consumption by $80 \%$ would be needed [9]. It is clear that a reduction of this magnitude requires a fundamental transition of the current production-consumption system driven by both lifestyle changes and the development of innovative, low-resource technologies, products and services.

An important component of such a transition is a research and innovation system that can effectively generate these low-resource product and service innovations [0]. However, our society is facing increasingly dynamic and complex challenges, such as population growth, aging society, development of mega cities, increased mobility, climate change and the increasing consumption of energy, land and water. To confront these challenges, we need to advance a diverse research and innovation network system, promoting solutions that bridge the boundaries between disciplines, sectors and groups of players of the sustainable production and consumption system [11].

Actors within the economic system - especially businesses - face the challenge of designing their processes as well as product and service innovations in a way that achieves a significant contribution to these sustainability goals (e.g., resource efficiency, climate protection etc.) while maintaining a high customer benefit at the same time [12,13]. As well as improvement measures within the company (such as material and energy savings during production), this requires measures that focus on optimizing the entire life cycle of a product and thus include improvement potentials in the use 
phase [14]. The sustainability of our production and consumption patterns is influenced considerably by supply and demand interactions a well as by the (way of) utilization of products and services [15]. Over the last decades, a large number of potentially more efficient technologies as well as products and services were developed without considerable integration of consumers - examples include car sharing, new heating systems, alternative light bulbs or detergents and electric kettles.

Many of these innovations did not lead to the desired effects due to unexpected user behavior and changing life styles: In the Netherlands for example, the water consumption for showering has increased by around $30 \%$ despite water saving fittings, because longer and more frequent showers are taken [16]. The technologically possible efficiency gains were even overcompensated by changing behavioral patterns. The integration of actors and users into the development of products and services could contribute to understanding such systemic effects and by doing so could release great potentials. For example, estimates show that around $26 \%-36 \%$ of the energy consumption in households can be influenced by behavior modifications [17]. The inclusion of users in an early phase of the development of products and services can help to preclude problems and to define and compare demands and strategies. Thus, it can enhance the competitiveness and ecological soundness of socio-technical innovations [12].

In research and product development, the interfaces of socio-ecological transformation of consumption patterns have received little attention so far. This is caused, amongst other factors, by the fact that facilities for explorative and experimental research in real-world surroundings (e.g., household laboratories) are lacking [18,19].

To overcome the shortcomings and meet the challenges of present research and innovation systems described above, Living Labs for Sustainable Development present a promising network and actor-interaction approach with flexibility of the research design to combine real life or work observation settings, prototype development and field tests $[12,13]$. This paper describes the development potential for and the keystones of a user- and actor oriented future research- and innovation infrastructure in Germany, which will use the potential of the Living Lab approach to foster energyand resource efficiency innovations to contribute to long-term sustainable development. It focuses on identifying the measures and strategies needed to develop such a research infrastructure in Germany. To identify these measures a number of tasks were performed, starting with the analysis of the status quo of the German Living Lab landscape, to the identification of the most promising fields of application, the analysis of drivers and barriers and development of a SWOT profile, which led to the deduction of strategies and measures for the development of the necessary research infrastructure. These research steps and the methods used are elaborated in Section 2 of the paper, which also gives a short introduction to the concept of Living Labs for Sustainable Development. Section 3 then presents the results of the status quo analysis, the identified fields of application, the drivers and barriers and SWOT analysis. The strategies and measures that were drawn from these results are discussed in Section 4. Finally, the key outcomes of this research are summarized in the concluding Section 5.

\section{Methodology for Assessing the Potential of a German Living Lab Research Infrastructure}

This section firstly formulates a working definition of Living Labs for Sustainable Development, which are seen as a promising approach to align a user- and actor-integrated research and development 
infrastructure with the goals of sustainable development. The second part of the section then describes the research steps and methods used to identify measures to develop a strong, networked infrastructure of Living Labs for Sustainable Development in Germany.

\subsection{The Living Lab Concept}

The Living Lab concept was originally developed at the Massachusetts Institute of Technology (MIT) [20]. Living Labs aim at identifying and realizing the potential contribution of integrating users and actors for the successful and effective generation of innovations in production-consumption systems. Production and consumption are understood as a holistic system that interacts across all steps of the value chain, comprising all actors who are directly or indirectly involved in the production of products or services. All flows of materials, value and information are considered, as well as organisational aspects regarding the coordination of the actors [21]. The initial assumption is that the (re)design and the development of products and services directly or indirectly influences the sustainability, including the individual, social and environmental compatibility, of the entire value chain, from resource extraction, production and use to recycling and disposal [22].

The general potential and operationalization of Living Labs specifically for sustainability was outlined in a European design study [12]. Their goal is to integrate the expert knowledge of users within their action system into the development of socio-technical, transformative products and services, as well as to test, optimize these products and services together with users and other actors along the value chain. Thus, optimal and accepted framework conditions for transition processes towards resource- and energy efficiency can be created [19]. Living Labs create a platform on which different methods of user integration into the innovation process can be tested (e.g., ranging from observation to application testing and even co-creation). In Living Labs, various elements of the real-world surroundings can be configured in a way that enables the researcher to address and observe real utilization patterns.

In Living Labs for sustainable development, users are involved in the development of resource and energy efficient innovations. They are supposed to be included both in the definition of the problem and the development, testing, realization and dissemination of the solution. In experiments, product-service systems can be studied in a context that is close to reality and considers the specific cultural and social context. The goal is an alignment with the needs of the users and with sustainability criteria during the entire development process. Thereby the risks of undesirable developments and problems of acceptance can be reduced. For the study, the Living Lab is defined as follows:

“A Living Lab for Sustainable Development (or Sustainability Living Lab) is a research approach aimed at open socio-technical innovation processes, in which users as well as relevant actors of the value chain and the utilization environment participate in the development and application of new products, services and system solutions. The interactive innovation process takes place in the real environment of the users (e.g., user observation, field tests) and/or in laboratories that are configured for user interactions (e.g., for the development of prototypes). The innovation process is guided by sustainability criteria and aims to contribute to production and consumption patterns that can be applied on the global and long-term scale and are inter- and intragenerationally viable." 


\subsection{Research Steps and Methods}

The analysis of the potentials of a German Sustainability Living Lab research infrastructure for the user-led development of sustainable products and services, as well as preconditions for its realization, is based on the concept of innovation and technology analysis (ITA). ITA is a strategic concept for the analysis and evaluation of technologies that integrates research with practical considerations $[23,24]$. The integration of relevant experts and stakeholders in discussions concerning innovations and new technologies is an important part of this approach. In total, 41 experts and stakeholders have been involved. The research was conducted in five steps, as outlined below:

Step 1: First, the German research and development $(R \& D)$ landscape was screened with the aim to characterize the Living Lab landscape that could be relevant for a future Living Lab for Sustainable Development research infrastructure in Germany. This includes Living Labs in neighboring countries and temporary projects. This analysis of the status quo is needed to be able to develop targeted measures for the development of the research infrastructure, which include already existing institutions and can fill identified gaps. On the basis of Internet and literature research, laboratories were identified and classified based on their potential to develop or evaluate innovations in terms of their environmental effects. It was analyzed whether the laboratories explicitly considered sustainability aspects or whether they implicitly worked on topics that could be relevant to sustainability. Furthermore, the level of institutionalization of the laboratory was investigated. An explicit consideration of sustainability was assumed when this was stated in the Living Lab program. An implicit consideration of sustainability was assumed based on the content of current projects run by the Living Lab. This was the case when the project focus was on areas with high resource intensity and high resource saving potential, particularly energy, nutrition, mobility, housing and work life. To evaluate the level of institutionalization, a differentiation was made between Living Labs which are run only as a single project (low degree of institutionalization), and Living Labs which are permanently established in terms of facilities and practice (high degree of institutionalization). Eleven operators and users of the identified laboratories were interviewed on the physical realization of the laboratory, the thematic focus, the methods used, the connection to sustainability, and the potential development options.

Step 2: Furthermore, fields of application that promise a high potential for benefiting from user integration in the innovation process were identified. The focus was on technologies, products and services which have the potential to significantly reduce resource consumption, i.e., can boost resource efficiency. This step was conducted to clearly define the directions of a future research and development infrastructure using the Living Lab approach and to highlight research priorities of such an infrastructure. A literature search was conducted to identify technologies, products and services with high resource efficiency potential on the one hand, and high potential for development in Living Labs on the other hand. This search initially yielded 400 studies. After screening for relevance and depth of analysis, this number was reduced to $c a$. 100 studies for further analysis. In a next step, the relevant product, technologies and services identified from the literature were grouped into areas of application known to be highly relevant for resource consumption on the household level. This high-level grouping structure was developed based on results from previous studies [9,12,24-27]. From this structured list, those products/technologies/services with the highest potential for resource efficiency and applicability in Living Labs or Sustainable Development were selected by the project 
team based on a set of criteria developed by Rohn et al. (2009) [28] and adapted for this study (see Table S1). Finally, results were supplemented and evaluated through expert interviews and discussions in a potential-validation workshop [29]. The final results from this research step are presented in Section 3.2.

Step 3. In the next step, conditions for the creation of an innovation-oriented and internationally competitive research and development infrastructure in Germany were analyzed. The drivers and barriers for a functioning German Sustainability Living Lab infrastructure were identified by conducting a further literature analysis and five expert interviews. This analysis was needed to identify which barriers need to be addressed by specific measures to aid the implementation of a Living Lab research infrastructure.

Each step benefited from extensive dialog with experts, which took place in two expert workshops. The starting point for the dialog was the analysis of the national innovation system, which on the one hand consists of the laboratories identified in Step 1 and on the other hand of all actors that have either a direct connection to these laboratories (e.g., client and supplier relationships) or define the framework conditions for Living Labs (e.g., political actors and groups of society). From the analysis of the national innovation system, from the field of sustainable development in general, and from the Living Lab community, 350 actors were identified and evaluated with regard to their relevance for this project. Sixty of these actors were rated as highly important based on their orientation towards innovation, consumers and sustainability. The dialog with these key actors was conducted in two workshops, the above-mentioned potential-validation workshop and a workshop on future perspectives [30]. In the first workshop, the results of the first two steps of the project were presented and discussed with experts from the areas of Living Labs, innovation research and sustainability research. In the second workshop, the prospects for a course of action to establish a German research infrastructure for sustainability innovations in Living Labs were discussed with representatives from Living Labs, Smart Home initiatives, design, socio-cultural research, innovation and sustainability research, and environmental organizations.

Step 4. In the next step, project results were condensed into a profile of strengths, weaknesses, opportunities and threats (SWOT) of the German research and innovation system. The SWOT analysis covered the general structure and performance of the Living Lab landscape as well as its orientation towards sustainability. The analysis was supported by a series of interviews with Living Lab practitioners and expert workshops.

Step 5. Based on this SWOT profile and the results from the expert workshops and interviews, options for practical measures and strategies for the implementation of a successful research infrastructure of Living Labs for Sustainable Development in Germany were discussed as the final step.

\section{Results: Points of Departure for the Development of a Sustainability Living Lab Infrastructure in Germany}

\subsection{Step 1: The Status Quo}

As a first step, an exploration and analysis of the status quo was conducted. This analysis of the existing infrastructure showed that in the current practice the term "Living Lab" is used to describe a 
broad range of laboratories and research approaches. Based on desk research and amendments in the expert workshops, a total of 76 Living Labs were identified in Germany and neighboring countries (see list of Living Labs in the Table S2). Figure 1 depicts their geographical locations, as well as the degree to which sustainability is considered in these Living Labs and the level of their institutionalization, as described in the Section 2.2 (Step 1). 40 of the 74 Living Labs consider sustainability aspects. Of these, 12 Labs have an explicit connection to sustainability in their work, while in 28 Labs this connection is only implicit. 34 Living Labs show a high level of maturity regarding their degree of institutionalization. Three German Living Labs are both fully institutionalized and have a direct connection to sustainability: The Efficiency-House-Plus in Berlin, the Fraunhofer-inHaus-Center in Duisburg and the SAP Future Energy Center in Karlsruhe (see Table 1).

Figure 1. Living Labs identified in Germany and neighboring countries (Status: April 2012) (Own depiction by authors Stabe, Schnalzer and von Geibler).

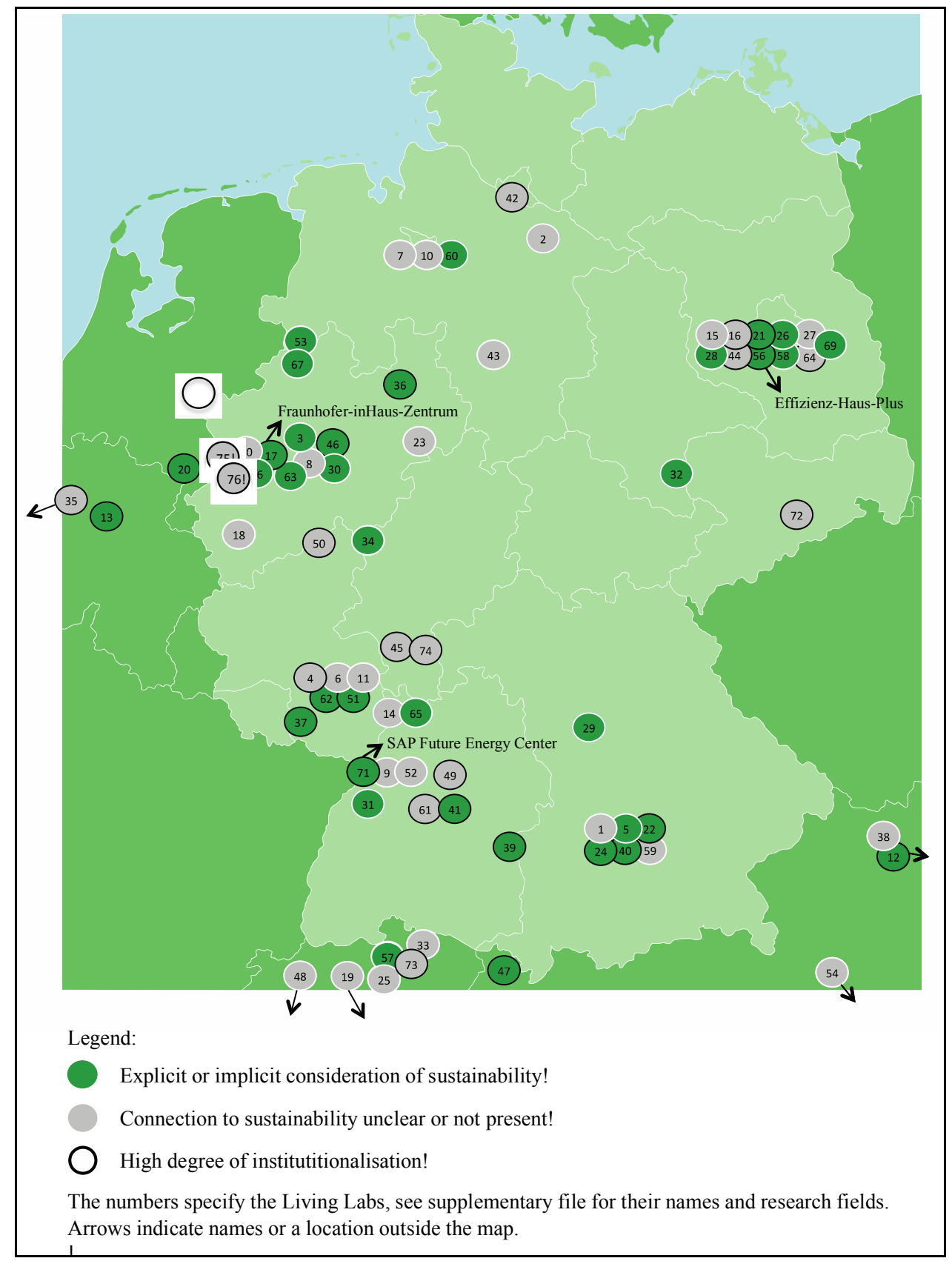


The status quo analysis revealed that many of the identified Living Labs are facilities that were established in the context of fixed-term projects. While these Labs are linked to a network of project or cooperation partners in the region, strategic networking with other Living Labs on the national or international level does not exist in most cases. The distribution of Living Labs in Figure 1 shows some potential for regional clusters, particularly in the areas of Berlin, Kaiserslautern, in the Ruhr area, Karlsruhe/Stuttgart and Munich, where institutionalized Living Labs with at least an implicit connection to sustainability exist already. According to experts participating in the workshops, these regional competencies should be further explored including the relations between the actors and organizations. Furthermore, some sustainability focused research consortia with an international orientation exist already, for example the innovation infrastructure "SusLab NWE" (Sustainable Labs North West Europe), which includes actors from North-Rhine-Westphalia [31].

Thematically, many Living Labs focus on the areas of Ambient Assisted Living, Smart Homes and Smart Building related activities, ICT, infrastructure and work environments (see Table S2) for research areas of Living Labs). Most Living Labs aim at demonstration, evaluation and validation of innovative technological solutions. Explorative approaches like open and unbiased observation or participative co-creation are hardly observable. Within the Living Labs explored in the 11 interviews, sustainability aspects were not considered to be a core interest. The sustainability concept was often not clearly defined. Activities mostly focus on economic or business issues, e.g., on the development and diffusion of technological innovations, or on social aspects, e.g., maintaining autonomy and inclusion of the elderly in society. While these topics are of high relevance to sustainable development, environmental aspects such as energy consumption and resource efficiency need yet to be included. This result has confirmed the relevance of the next step in this research.

Table 1. Three fully institutionalized laboratories with an explicit focus on sustainability in Germany.

\begin{tabular}{cl}
\hline Effizienz-Haus-Plus in Berlin & $\begin{array}{l}\text { The home for a family of four supports the resource efficient use of synergies } \\
\text { between housing and mobility. The energy generated by the house is stored and used } \\
\text { to charge electric vehicles. The everyday life suitability of the model house is being } \\
\text { tested for } 15 \text { months [32]. }\end{array}$ \\
\hline $\begin{array}{c}\text { Fraunhofer-inHaus-Zentrum } \\
\text { in Duisburg }\end{array}$ & $\begin{array}{l}\text { The Fraunhofer-inHaus-Zentrum is an innovation center for novel system solutions in } \\
\text { rooms and buildings. There are two units, one for the residential sector (Smart Home) } \\
\text { and one for the commercial sector (Smart Building) [33]. }\end{array}$ \\
\hline The Future Energy Center is a collaborative demonstration platform for the \\
in Karlsruhe & $\begin{array}{l}\text { The Fortunities of innovative IT for sustainable energy generation, distribution, storage } \\
\text { and use. From this platform, several research projects are conducted [34]. }\end{array}$ \\
\hline
\end{tabular}

\subsection{Step 2: What Areas of Application Promise the Greatest Sustainability Potentials?}

Many product or service innovations fail because of low user acceptance, or they cause negative rebound effects due to unexpected user behavior. Direct and indirect rebound effects and failed technical adaptation to the real life and work environments of users and applicants cause inefficiency and ineffectiveness, so that physically possible potentials cannot be implemented and realized. It is assumed that low resource use products and services can be developed in Living Labs for Sustainable Development, as demonstrated by several examples [13,35-37]. Living Labs have the function 
to observe the interactions between people and technologies in real-world utilization contexts. By combining new technologies and application practice, they can help to realize innovation potentials, as consumer behavior can be observed more systematically. Based on the literature review, Living Labs for Sustainable Developments appear to have the potential for developing strategies to increase user acceptance for low resource use products and services while minimizing negative systemic effects (e.g., rebound effects) [38,39].

One particular type of systemic effects are rebound effects. These occur when resource savings (e.g., electricity savings) liberate new resources (e.g., money), which generate new resource consumption (e.g., spending the saved money on added consumption). The liberated means can be invested into increased consumption of the same good (direct rebound effect), for example a more fuel-efficient car is used to drive more kilometers, resulting in higher fuel consumption in total. They can also be invested to consume alternative goods and services, which use energy and resources (indirect rebound effect). In this case, the magnitude of the rebound effect depends on the resource consumption of these alternative products or services [40-43]. Rebound effects are one of the greatest challenges of current applied sustainability science and an important argument for the necessity to develop an infrastructure of Living Labs for Sustainable Development. Using Living Labs, the currently thin empirical basis for the understanding of systemic effects can be broadened.

The analysis of potential areas of application identified several relevant areas for Living Labs for Sustainable Development. The focus was put on application areas that can be directly influenced by the user, since users have numerous options to influence the sustainability effects of their actions. They can undertake several activities (e.g., planning, researching, shopping etc.) in different modes (e.g., physically, online, etc.). These modes of the different activities can all be addressed in Living Labs, i.e., the user is observed in the specific environments, is integrated into innovation processes and the innovation is then tested in the specific environments. A European feasibility study conducted in 2010 [12] focused on housing and its effects on sustainability. Energy and water consumption as well as waste generation were at the center of the investigation. This analysis on the potential areas of application for Sustainability Living Labs confirmed the results of the earlier study [12]. However, the scope and research approach were broadened to include further areas for user integrated sustainability innovations beyond housing. Under consideration of the results of the Living Lab study from 2010 as well as existing studies on resource efficiency potentials [9,24,25,27], the following areas of application were identified as particularly relevant in terms of natural resource consumption: (1) Living and working; (2) Town, region and mobility; (3) Retail and gastronomy. For each of these areas of application, several particularly relevant product groups, technologies and services were identified following the procedure described in Section 2.2.

The analysis shows that there are various potential application areas for Living Labs for Sustainable Development. Additionally, results from interviews and workshop discussions revealed that there are two distinctly different research perspectives among experts regarding relevant areas of application for Sustainability Living Labs. Thus, results were further differentiated into these two complementary research perspectives, namely "user behavior" and "product innovation".

The field of product innovation focuses on the development of product groups and service bundles that are resource-efficient and sustainable along the entire value chain. Due to a more intense user involvement in the innovation process, it is assumed that the user acceptance of so developed products 
and services can be increased significantly. This applies to products and services with positive as well as negative potentials for sustainability (To ensure that positive effects for sustainability are achieved, it is necessary to conduct sustainability assessments in the product development phase. A practical indicator to assess the benefit of new products for resource efficiency is the material footprint). Therefore, it is important to ensure that the diffusion success of sustainable products and services is promoted by integrating users in the innovation phase. Living Labs offer one of several ways of enhanced user integration.

Regarding consumer behavior, the change of the user's behavior towards more sustainable lifestyle and consumption patterns is of special interest. By simulating a realistic living environment within the Living Lab, the systemic micro level effects of products and services can be examined and addressed. User acceptance as well as rebound effects can be partly revealed by Living Labs and innovative solutions can be developed. The aim of this research is to identify behaviors and patterns that can be supporting or hindering factors in the conduct and development of sustainable practices in everyday life. These concepts and approaches can be utilized for directly supporting changes in user behavior, e.g., in education and communication activities, as well as a basis for research on the development and implementation of product innovations.

Table 2 lists the identified product groups/technologies/services with high resource efficiency potential and high potential for development in Living Labs. Based on the findings discussed above, results are grouped into the three particularly relevant areas of application ((1) Living and working; (2) Town, region and mobility; (3) Retail and gastronomy), as well as the two research perspectives "user behavior" and "product innovation".

Table 2. Overview of relevant fields of application identified for Living Labs for Sustainable Development (own depiction by authors Rohn and Leismann based on literature review and workshop results).

\begin{tabular}{lll}
\hline Field of & \multicolumn{2}{c}{ Research Perspective } \\
\cline { 2 - 3 } Application & Product/Service Innovations & User Behavior \\
\hline & Building and infrastructure, e.g., security, heating & Behavior at home and workplace, e.g., \\
and energy supply, insulation, e-energy/energy & health and exercise, energy consumption \\
& assistance & Nutrition, e.g., food wastage, shopping, \\
& Food, e.g., chilling, storage, preparation, assistants & health \\
& Health and hygiene, e.g., medical care, fitness, & Phase of life appropriate design of \\
medical technology & home/workplace, e.g., autonomous life at \\
Wife and & Furnishings of living and working spaces, e.g., & old age, user acceptance of innovations \\
& design of electric and electronic equipment, & Integrated design, e.g., in the area of \\
& furniture, textiles & fields of demand or service design \\
& Information management, e.g., communication in & Furnishings of living and working \\
& the home/out of home, ICT products and their use & spaces, e.g., new workplace concepts, \\
& Substitution of physical mobility by "ICT & ways of utilization, cascading systems, \\
& mobility", connection to logistics systems, & ICT \\
& Smart Grids & Service and time management, e.g., \\
& & being mobile, eating healthy, exercise \\
\hline
\end{tabular}


Table 2. Cont.

\begin{tabular}{|c|c|c|}
\hline \multirow{2}{*}{$\begin{array}{l}\text { Field of } \\
\text { Application }\end{array}$} & \multicolumn{2}{|c|}{ Research Perspective } \\
\hline & Product/Service Innovations & User Behavior \\
\hline $\begin{array}{l}\text { Town, } \\
\text { Region and } \\
\text { Mobility }\end{array}$ & $\begin{array}{l}\text { Out of home catering, e.g., delivery services, } \\
\text { drive-in restaurants, etc. } \\
\text { Mobility, e.g., efficient mobility options (logistics), } \\
\text { freight, public transport linkages, design of } \\
\text { mobility options } \\
\text { Regional networks/“location promotion”, e.g., } \\
\text { health support systems, urban planning, } \\
\text { communication systems, regional energy supply, } \\
\text { tourism, sharing and renting options }\end{array}$ & $\begin{array}{l}\text { Mobility, e.g., use and user acceptance of } \\
\text { resource efficient mobility options } \\
\text { Communities/networks, e.g., urban } \\
\text { agriculture, barter systems, neighborhood } \\
\text { networks, service concepts and } \\
\text { suburb development } \\
\text { Leisure/holiday behavior, e.g., } \\
\text { regional tourism } \\
\text { ICT services, e.g., integrated ICT, } \\
\text { mobility and logistics management }\end{array}$ \\
\hline $\begin{array}{l}\text { Retail and } \\
\text { Gastronomy }\end{array}$ & $\begin{array}{l}\text { Furnishings, e.g., electric and electronic } \\
\text { equipment, lighting, media, online shopping, design } \\
\text { Mobility, e.g., efficient mobility options } \\
\text { Nutrition, e.g., food labelling and declaration } \\
\text { Support at old age, e.g., intelligent appliances }\end{array}$ & $\begin{array}{l}\text { Intelligent appliances, e.g., } \\
\text { digital product memory } \\
\text { Choice of products, e.g., influence of } \\
\text { advertisement and information campaigns }\end{array}$ \\
\hline
\end{tabular}

\subsection{Step 3: Drivers and Barriers for a Sustainability Living Lab Approach}

The project identified a number of potential drivers and barriers for the establishment of an infrastructure for the development of sustainability innovations in Living Labs. This was done on the basis of a literature review, expert interviews and workshop discussions. Based on the promoter model of Hauschildt and Gemünden (1999) [44] factors potentially affecting the implementation of the envisaged Living Lab infrastructure were categorised as pertaining to the realms of expertise, power, process, and relationships.

The following expertise-related factors have been stated by interviewed experts to be particularly beneficial for the development of a Sustainability Living Lab infrastructure:

- Systematic utilization of sustainability indicators such as MIPS, Material Footprint, Carbon Footprint, GRI indicators [7,8,45-48] and assessments, which consider long-time horizons and high case numbers; and

- A sensitivity to cultural barriers that could be in the way of considered socio-technical approaches towards more sustainable patterns of production and consumption.

Based on interviews and expert statements in the workshops, the following expertise-related factors seem to be particularly detrimental to the development of a Sustainability Living Lab infrastructure:

- Time-constrained and reductionist research designs; and

- A lack of competency for inter- and transdisciplinary communication among researchers and between researchers and users.

With regard to the role of power-related factors, experts state the necessity to ensure long-term public financing due to the high share of basic research to be conducted. Many current Living Labs are owned by companies and run for the benefit of the company, with sustainability playing only a marginal role. At a more general level, it is advantageous to have a regulatory framework that: 
- Drives business to internalize formerly externalized costs;

- Protects niches for innovative activities (particularly in order to guard from premature commercialization and lock-in); and

- Implements measures for the protection of unbiased, technology-neutral and sustainability oriented research.

The following barriers can be identified based on the expert interviews and workshop discussions from a power perspective:

- Short time horizons and premature or special interest-led choices for specific technologies;

- Product-centric business models that are opposed to the implementation of systemic, service-oriented and resource efficient innovations;

- Unwillingness to make the impact of technologies comparable or the desire to merely advertise specific products;

- Low visibility of Living Lab potentials, which stands in the way of broader reception at the communal and regional political levels;

- Rivalry in the research and development field, which can stand in the way of open innovation processes;

- Undue advantages for specific technologies as a result of exclusive public support for specific experiments.

With regard to process aspects, experts estimate that it is advantageous to ensure sufficient freedom for developers so that they can enjoy creativity and the willingness to take risks. It also seems advisable to work towards a dynamic support for those solutions that exhibit the most promising development patterns by establishing an evaluation framework that works in proximity to the process. Barriers be seen in the high burden of time and effort that need to be invested in ensuring optimal assistance for and interaction with the users (mentioned by operators of living lab in Germany), risk averse funding principles of public funding bodies that are not ideally tailored to the needs of innovative and sustainability-oriented activities and a lack of the flexibility that is needed in order to support or participate in dynamic innovation processes that include a wide array of different actors (result of workshop discussion).

The workshop discussions revealed that, regarding relational aspects, it is important to keep users motivated and to test and support, if necessary, their ability for reflection on their behavior. Thus, the social relations to users should be at the center-stage of Living Labs for Sustainable Development. In order to ensure this, the inclusion of a moderator who can foster trust and understanding between users and researchers is advisable. On the other hand, companies' focus on technical functionalities and their lack of appreciation for research on users' acceptance of products and services poses an important barrier to the success of Living Labs.

According to interviews with experts and living lab operators, different expert cultures and terminological barriers between social science and humanities, on the one hand, and technology-oriented sciences, on the other hand, can make cooperation in Living Labs difficult. At the same time, the transdisciplinary character of Living Labs poses a barrier for their inclusion into the science system. For the successful implementation of Living Labs for Sustainable Development all participants of the second workshop agreed that it will be necessary to integrate sustainability research, design, 
innovation and technology studies, social sciences and cultural studies. Living Labs could provide a platform for furthering exchange between the design discipline and more scientifically-oriented disciplines.

Furthermore, the integration of dynamic feedback processes that support reflexive learning and goal adjustment is important in order for Living Labs for sustainable development to fully leverage their potential impact.

\subsection{Step 4: SWOT for the Implementation of the Living Labs for Sustainable Development Approach}

All Living Lab operators which were interviewed for the status quo analysis of the study saw Living Labs as a promising approach for supporting sustainable development in Germany. An important precondition for this to succeed - not least in order to enable the validity of the prior statement - would be a conceptual clarification of the meaning and implications of sustainable development. Methodological challenges arise from the necessity to observe user behavior in spatially as well as temporally distributed ways, which cannot be sufficiently confronted by current Living Labs. Living Labs for sustainable development may thus serve as a mediation instance for sustainability related research questions and could provide a strategic framework for existing facilities.

Regarding conditions that would support the operation of Sustainability Living Labs, experts interviewed indicated that long-term, topically open-ended and thematically flexible funding schemes that do not force premature focusing on product commercialization would be helpful. Moreover, there is a need to develop concepts regarding sustainable development that can be meaningfully implemented and operationalized via Living Labs in real-life fields of application. Practically, start-up (seed) financing and operationally viable business models would have to be elaborated, too. To achieve the latter, lessons can be learned from business models of fairly long-term existing laboratories such as the Fraunhofer-inHaus-Zentrum. These labs have specific profiles which complement each other in the area of sustainability research and could serve as a core for the development of an infrastructure for user integrated, sustainable product-service-systems research. As a future scenario for Living Labs for Sustainable Development, established permanent research facilities could be complemented with mobile and/or temporary research settings to operate in real life locations of specific interest. This would have to be supported methodologically, e.g., via ethnographic approaches to address spatially and temporally disperse phenomena, and could be a low-cost option to consider the heterogeneity of utilization patterns. As sustainability inherently involves distributed phenomena, networking on both national and international scales should be cultivated. This should also include the further development of competences concerning cross-cultural and cross-disciplinary comparative analyses and concept development amongst highly diverse collaborators.

Based on the results described above, the Strengths and Weaknesses, Opportunities and Threats (SWOT) for Living Labs for Sustainable Development in Germany are derived. The SWOT analysis is intended to inform strategies and measures for a successful integration of the Living Lab approach into the German research and innovation system. It provides an overview of both the strengths and opportunities of the German research and innovation system, and the weaknesses and threats that need to be addressed to ensure the success of Living Labs for Sustainable Development within the German research and innovation infrastructure. The results are summarized in Table 3 and elaborated below. 
Table 3. Strengths and Weaknesses, Opportunities and Threats (SWOT) of the German research and innovation system for the development of Living Labs for Sustainable Development (Source: Own depiction based on expert workshop results).

\begin{tabular}{c} 
Strengths \\
\hline - Acceptance of sustainability: Sustainability
\end{tabular}
is a broadly accepted goal, which can be referred to.

- Existing Living Labs are complementary to the technology-focused research landscape:

Living Labs enable the integration of non-technical aspects in technical innovation processes.

- Existing regional clusters: A "place" is important to connect actors.
Weaknesses

- Lack of capacity: Systems design and mediation capacities should be developed, e.g., to bridge between "soft" approaches like user-integration and "hard" technology-centered approaches.

- Opinion of limited commercially usable outcomes: Results of experimental research do not necessarily yield commercially viable products in the short-term. The commercial usability of sustainability solutions could be enhanced by including businesses in the development process.

\begin{tabular}{l} 
Opportunities \\
\hline Realization of efficiency potentials under \\
consideration of rebound effects on the \\
micro-scale: A user-centric development \\
process can increase user acceptance and be \\
crucial for product success.
\end{tabular}

- Potential to connect different strands of research: Research at the interfaces between sustainability, innovation and userintegration already exist but are largely unconnected.

- Existing international networks of Living Lab research should be integrated.

- Capacity development at universities: Universities offer infrastructures for mediators between user needs, sustainability aspects and technological perspectives.

\section{Threats}

- Short-term thinking in business strategies:

The research design of Living Lab projects could insufficiently consider implementation perspectives.

- Data security issues: The sensitivity of data on consumption and behavioral patterns cannot be integrated sufficiently in Living Labs if not considered e.g., by implementing accompanying ELSAassessments.

- Compatibility of assessed micro-data: Data sets from Living Labs might be incompatible with macro-data on the societal system, if data interfaces and assessment conventions are not defined (The compatibility with macro data is helpful when comparing potential environmental or social improvement of a specific case with reference values at the macro-level. If data sets are incompatible, comparisons are less meaningful.).

The key opportunities of the research and innovation system are centered on the possibility to integrate different methods of user-integration into the innovation process (see e.g., [49]). Thereby, different elements of the real-world environments can be configured in ways that enable the observation and addressing of real usage patterns in Living Labs to combine real life environments, co-creation for prototyping and field tests. These opportunities form the basis for the realization of efficiency potentials under consideration of rebound effects on the micro-scale. The relevance of these efficiency potentials, e.g., regarding the reduction of greenhouse gas emissions and natural resources consumption or investment and diffusion costs, can then be modelled and estimated for the macro-economic scale. However, results are only applicable to the macro-scale if specific conditions are met, such as the application of multi-scale assessment systems (e.g., environmental indicators that are applicable to different scales, such as material consumption (MIPS or TMR), greenhouse gas 
emissions or land requirements [8]) and a representative choice of observation spaces (e.g., households). Examples of indicators that can create a link between the micro- and macro scale are MIPS, TMR (Total Material Requirement) and TMC (Total Material Consumption). MIPS is a micro-level indicator, which assesses the resource consumption of products or services. The sum of biotic and abiotic material inputs and erosion in MIPS can be considered together as the "Material Footprint" of the product or service, which is then equivalent to the resource categories used when calculating "total material requirements" (TMR) at macroeconomic level [8]. Furthermore, Living Labs have the potential to support refining the MIPS concept. The focus on user needs and product-service systems solutions in Living Labs for Sustainable Development offers opportunities to investigate and more clearly define the concept of the "Service Unit", which is the basis of the MIPS concept. Further strengths of the approach are that Living Labs represent a methodologically open space, which means that non-technical aspects can be integrated into the innovation process, complementing the existing technology-focused research landscape. The results and discussions with experts highlight the key role of the entrepreneur or "change agent", who should consider and balance all important aspects in the development process [50,51]. Already existing Living Labs i.e., regional clusters with connections to sustainability are also a strength, because a "place" as interaction nucleus and identity structure is important to connect actors. Such places already exist in Germany, for example the Fraunhofer-InHaus-Zentrum, the Effizienz-Haus-Plus or the SAP Future Energy Center.

A threat regarding the implementation of the Living Lab approach is the fact that data sets from Living Labs are not always compatible with macro-economic data, and that data interfaces and assessment conventions have not been well defined yet. Several research projects are currently addressing these important questions of transformation research (Such as the projects "SusLabNWE" [31] the project "globally sustainable material prosperity levels" [52], and the project "myEcoCost" [53]). A weakness of the German research and innovation system is seen by some experts in the opinion that results of particularly explorative innovation projects in Living Labs are only in parts commercially usable. This is because results of explorative research do not necessarily yield products that can be commercialized in the short-term. This problem can be mitigated by closely integrating businesses and their needs into the research design, as has been done in various existing or past living lab projects. The research and innovation design can be differentiated: it is possible to focus on the further development of existing technological applications or to develop needs-oriented newly combined technological applications, both with a direct marketing perspective. Furthermore, new innovations and systems solutions can be developed by integrating actors. Depending on the chosen approach, the short-term risk and research component of the project can be lower or higher-risks increase by venturing into "new territory". All of these approaches are relevant for the integration of both SMEs and large enterprises. Therefore, depending on the depth of innovation, Living Lab projects are possible in both privately funded cooperation and publicly funded research consortia. Larger scale opportunities for the integration of the Living Lab approach into the German research and innovation system arise from the increasingly acknowledged need to use synergies between different strands of research, for example on the interface of future research, empirical social research and sustainability research [54], between socio-ecological research and user integration (e.g. [55]) or in the field of socio-technical innovations [56]. Further opportunities exist to expand the research landscape by establishing sustainability as a broadly accepted goal. Already existing international networks of Living Lab research and capacity building at 
university can be the drivers to realize these opportunities. Universities can play an important role as capacity builders for transdisciplinary research. An integration of the Living Lab approach into Master's programs would be an opportunity to build capacities for transformation research (See e.g., for the identification and development of offers for all areas of education on resource saving and resource efficiency [57]). Master's programs should integrate trans- and interdisciplinary projects as a continual activity to develop the systems design capacity of students. These projects can be organized as campus projects or within research projects with external partners.

Short-term thinking in business strategies is one of the main threats to a broad implementation of Living Labs for Sustainable Development. To overcome this barrier, the research design can be defined in collaboration with the actors. In doing so, it needs to be decided whether already existent innovation paths are to be extended or if new paths are to be developed, targeting either short-term or long-term implementation. Another threat may arise in the area of data security, as data on consumption and behavioral patterns assessed in Living Labs can be very sensitive. To mitigate this risk, Living Lab projects should be accompanied by an assessment of ethical, legal and social aspects (ELSA). Finally, a lack of capacity can pose a threat for Living Labs, as currently there is a shortage of competent mediators between "soft" approaches like user-integration and "hard" technology-centered approaches. The development of a research and innovation system with Living Lab approaches can serve the stepwise building of transdisciplinary capacity [12,58,59]. More generally, the involvement of a critical mass of users is a success factor. In particular, Living Labs for Sustainable Development should address the mass of people, and not only lead users, in order to realize macroeconomic resource savings. Various platforms (e.g., [60]) provide incentives to large number of users to contribute to problem solving. Motivational aspects of user engagement in Living Lab innovation processes are to be explored systematically, for example the Living Labs operated by large companies (e.g., Philips, Eindhoven, the Netherlands; SAP, Karlsruhe, Germany)

The results of the SWOT analysis show that research in Living Labs, like many other innovation projects, entails certain risks. However, these risks can be mitigated by targeted measures. The results of the SWOT analysis fed into the development of options and strategies for action to integrate the Living Lab approach into the German research and innovation system, which are outlined in the next section.

\section{Discussion of Strategies and Options for Action (Step 5)}

Based on the project results as well as in discussions within the project consortium and with the participants of the expert workshops (experts from science, society, politics and business), a number of strategies and options for action have been identified. The improvement of the innovation climate for sustainable products and services in Germany and Europe was commonly agreed to be an important high-level task. Under consideration of this task, the project consortium unanimously agreed upon the following specific keystones for the development of a German research and innovation system based on Living Labs for Sustainable Development:

- The development of a research infrastructure for user integrated development of sustainable products and services. The goal is the generation of sustainable systems innovations, which have been tested for systemic effects, in German, European and international cooperative research networks. 
- Improved access to such a research and innovation system, especially for research institutes and companies who cannot maintain such an infrastructure themselves (e.g., small and medium sized enterprises).

- To enhance and speed up research and development of resource efficient, competitive and socially acceptable products and services that can contribute significantly to a system-wide reduction of resource consumption in the household or other fields of application, such as the point of sale.

- Improved networking amongst European researchers and conducting joint research projects. The strengthening of trans-national cooperation and competitive capacity, the development of the German research sector and economy and connectedness to international activities.

To achieve these goals, targeted strategies are needed. Based on the results, the authors suggest strategies and concrete options to integrate Living Labs for Sustainable Development into the German research and innovation system (see Table 4). There are two basic strategies. The interviews and workshops highlighted that the German Living Lab landscape is fragmented, poorly visible and not leveraging its macro-potentials: Thus, the authors - and selected interviewees - suggest a structure formation within the research and innovation system including networking and profile formation, the support the innovative capacity of SMEs, participative processes and the design competencies. To develop and demonstrate sustainability potentials of Living Labs in Germany in specific fields of application, a funding program "Living Labs for Sustainable Development" is suggested by several workshop participants. This could include the funding of lighthouse projects, the development of the scientific basis for multidisciplinary transition- and innovation research and an accompanying communication program.

Table 4. Strategies and options to integrate Living Labs for Sustainable Development into the German research and innovation system.

\begin{tabular}{l|l}
\hline \multicolumn{1}{c|}{ Strategies } & \multicolumn{1}{c}{ Options } \\
\hline \multicolumn{1}{c}{ 1. Structure Formation within the Research and Innovation System } \\
\hline $\begin{array}{l}\text { Networking and profile } \\
\text { formation of the so far } \\
\text { poorly contoured Living } \\
\text { Lab landscape }\end{array}$ & $\begin{array}{l}\text { Financial support of regional clusters with thematically complementary } \\
\text { profiles. The funding should include lighthouse projects and projects } \\
\text { conducted within clusters, as well as poorly institutionalized facilities for } \\
\text { experimental research that do not use the term "Living Lab"; } \\
\text { Networking and synopsis of results and experience gained in Living Labs, } \\
\text { e.g., through conferences or workshop series; }\end{array}$ \\
\hline $\begin{array}{l}\text { Promoting the innovative } \\
\text { capacity of SMEs }\end{array}$ & $\begin{array}{l}\text { Creating links between German Living Labs and international partners, e.g., in } \\
\text { EU research and innovation programs such as "Horizon 2020". }\end{array}$ \\
\hline $\begin{array}{l}\text { Strengthening } \\
\text { participative processes }\end{array}$ & $\begin{array}{l}\text { chain-wide joint projects; } \\
\text { Improve access to Living Lab innovation systems for SMEs. }\end{array}$ \\
\hline $\begin{array}{l}\text { Establish design } \\
\text { competency }\end{array}$ & $\begin{array}{l}\text { Promoting participation in innovation processes through Living Labs, e.g., in } \\
\text { sustainable urban development. }\end{array}$ \\
\hline & $\begin{array}{l}\text { Develop systems design competency through adapted education concepts for } \\
\text { actors from science, business, local authorities and households, e.g., under } \\
\text { consideration of milieu structures, socio-cultural approaches, social motions } \\
\text { research and communication research. }\end{array}$ \\
\hline
\end{tabular}


Table 4. Cont.

\begin{tabular}{|c|c|}
\hline ies & \\
\hline \multicolumn{2}{|r|}{ 2. Program "Living Labs for Sustainable Development" } \\
\hline $\begin{array}{l}\text { Lighthouse projects } \\
\text { - } \quad \text { Use potentials } \\
\text { - } \text { Initiate innovations } \\
\text { - Demonstrate } \\
\text { examples }\end{array}$ & $\begin{array}{l}\text { - Foresight process for the strategic alignment of national and regional innovation } \\
\text { initiatives based on network analyses of existing Living Lab clusters; analyses of } \\
\text { actor relationships and thematic foci; analyses of potentials for individual fields of } \\
\text { action under consideration of regional competition-relevant strategies; } \\
\text { - Invitation for tenders for integrative, inter-departmental lighthouse projects by the } \\
\text { German research ministry or other ministries in a competition for Living Labs to } \\
\text { promote creativity, innovation, reflection and multidisciplinarity. Addressing } \\
\text { specific fields of action, e.g., "user integration in life sciences and bio-economy", } \\
\text { "IT security in home automation", "sustainability in lead markets" (key } \\
\text { technologies, new materials), etc.; } \\
\text { - Funding of demonstration projects to lift the profile of the Living Lab approach } \\
\text { with its potential to integrate non-technical aspects into the development of } \\
\text { technologies and business models. }\end{array}$ \\
\hline $\begin{array}{l}\text { Basics of transition } \\
\text { and innovation } \\
\text { research } \\
\text { - } \quad \text { Transdisciplinary } \\
\text { innovation research } \\
\text { - } \quad \text { Interdisciplinary } \\
\quad \text { action research }\end{array}$ & $\begin{array}{l}\text { - Consolidation of empirical transition research regarding new approaches to } \\
\text { innovation, e.g., at the interface between experimental approaches of action } \\
\text { research and technology development; } \\
\text { - Further development of conceptional and methodological foundations regarding } \\
\text { the application of Living Labs in ELSA analyses and for environmental and } \\
\text { sustainability assessments, e.g., in product tests or business model development; } \\
\text { - Development of principles for sustainability oriented design research under } \\
\text { consideration of interdisciplinary, self-reflective Living Lab approaches in the } \\
\text { design process; } \\
\text { - Development of theories and concepts for inter- and transdisciplinary } \\
\text { education/didactics. }\end{array}$ \\
\hline $\begin{array}{l}\text { Accompanying } \\
\text { communication } \\
\text { - } \quad \text { Raise the profile } \\
-\quad \text { Create awareness } \\
\text { - } \quad \text { Enable exchange }\end{array}$ & $\begin{array}{l}\text { - Communication campaign for businesses, politics, households and research, e.g., } \\
\text { at subject-specific events, which are so far conducted without consideration of } \\
\text { sustainability aspects; } \\
\text { - Preparation of information materials and communication formats for stronger } \\
\text { involvement of SMEs, the trades, business associations, consumer-, } \\
\text { environmental-, and sustainability initiatives; } \\
\text { - Specify the concept of "Living Labs for Sustainable Development" and } \\
\text { introduction of the concept as a brand; } \\
\text { - Launching of a competition for lighthouse projects for "Living Labs for } \\
\text { Sustainable Development". }\end{array}$ \\
\hline
\end{tabular}

\section{Summary and Conclusions}

The status quo analysis of the German R\&D landscape revealed that a number of facilities exist, which could be integrated into a future Living Lab research infrastructure for Sustainable Development. However, many Living Labs only operated in fixed-term projects. Additionally, in most of the existing labs, sustainability is not a key consideration in innovation processes. Innovations for resource efficiency are hardly addressed in the existing Living Labs. Furthermore, explorative research approaches like open observation or participative co-creation are rarely used. To achieve viable outcomes for 
sustainable development, better networking between the labs and the innovation and sustainability arena is needed.

Three application fields were identified as particularly suitable for investigation in Living Labs: Living and Working, Town, Region and Mobility, and Retail and Gastronomy. These fields were shown to be particularly relevant in terms of natural resource consumption with high potential for improvement. At the same time, they are strongly influenced by user behavior, thus innovations in these fields have great potential to benefit from user-integration. Within these fields of application, it is helpful to differentiate between two complementary research perspectives: "User behavior" and "product innovation". The user behavior perspective focuses on the change of the user's behavior towards more sustainable lifestyles and consumption patterns. User acceptance, systemic effects (such as rebound effects), and supporting or hindering factors for sustainable practices are of particular interest from this perspective. The product innovation perspective focuses on the development of product groups that are resource-efficient and sustainable along the entire value chain. Due to a closer user involvement in the innovation process, the products can be optimized and user acceptance in the diffusion phase can be increased significantly.

Drivers and barriers for sustainable innovations in Living Labs were classified in relation to expertise, power, process, and relationship factors. Some of the key conditions for a successful Sustainability Living Lab infrastructure include long time horizons for research projects, enabling open-ended innovation processes, reflexive learning and strong transdisciplinarity, systematic sustainability assessments that are integrated into the innovation process, and the consideration of socio-cultural factors in user behavior and acceptance. In a SWOT analysis, the main strengths and weaknesses of the German research and innovation system were summarized and the opportunities and threats regarding the development of Sustainable Living Labs were highlighted. For example, it became apparent from the workshop discussions, that Living Labs offer the opportunity to integrate sustainability research, design, innovation and technology studies, social sciences and cultural studies. In this context, Living Labs could provide a platform for transdiciplinary exchange and research.

Based on the results, the keystones of developing a research infrastructure for user integrated development of sustainable products and services, improving access to such a research and innovation system, enhancing and speeding up research and development of resource efficient, competitive and socially acceptable products and services, and improving networking amongst European researchers were formulated.

There are still a number of aspects which could be further explored. For example, both the relation of the living labs with existing initiatives, actors and organizations, and the most relevant living lab services are issues for further research. Furthermore, the fully institutionalized laboratories with an explicit focus on sustainability identified in Germany could be analyzed and compared more detailed, e.g., with regard to associated cost, benefits and impacts. In addition, more detailed international assessment and cross-country comparison of experiences in Living Labs for Sustainable Development are suggested.

Despite the soft contours and the heterogeneity of the German Living Lab landscape, as well as the still limited research body on the current practice in Living Lab for Sustainable Development, some tentative recommendations can be provided. They include, in a first step, an improved structure formation in the German research and innovation system, aiming at networking and profile formation, the support of SMEs to get access to the Living Labs, participative processes and the strengthening of 
transdisciplinary research and innovation competencies. Then, in a second step, markets and specific services of Living Labs for Sustainable Development could be explored in different fields of application, and, if this is successful, to promote Living Labs for sustainability in specific funding programs. Anchor points for the further development for the German research and innovation system could be those Living Labs which are established in different fields of application.

\section{Acknowledgments}

We are grateful to Kathrin Greiff, Nino David Jordan and Michael Wirtz for their contributions to the project. We acknowledge the research funding received from the German Ministry of Research and Education for the project "Nachhaltigkeitsinnovationen im Living Lab" (grant No. 16I1624 and 16I1625).

\section{Author Contributions}

The authors contributed to the paper in several ways. All authors, except Katharina Kennedy, were members of the project team, lead by Justus von Geibler. Justus von Geibler, Lorenz Erdmann and Christa Liedtke developed the concept and structure of the paper and did extensive work in internal reviews of paper drafts. Matthias Stabe and Kathrin Schnalzer characterized the German research and development (R\&D) landscape (step 1). Matthias Stabe, Kathrin Schnalzer and Justus von Geibler developed Figure 1 in close collaboration with Christa Liedtke. Holger Rohn and Kristin Leismann identified potential fields of application for living labs (step 2). Justus von Geibler contributed to the identification of drivers and barriers for a functioning German Sustainability Living Lab infrastructure (step 3) and coordinated the SWOT analysis (step 4) with contributions from all project members and external experts. Lorenz Erdmann and Simon Berner conceptualized and organized the extensive dialog with experts with contributions of all project members. The chapters Discussion of Strategies and Options for Action (step 5) and Summary and Conclusions originate from collaborative work led by Lorenz Erdmann, Christa Liedtke and Justus von Geibler. Justus von Geibler coordinated the writing and review process. Katharina Kennedy contributed by undertaking literature reviews, translations, English corrections and editing.

\section{Conflicts of Interest}

The authors declare no conflicts of interest.

\section{References}

1. Fischer-Kowalski, M.; Swilling, M.; von Weizsäcker, E.U.; Ren, Y.; Moriguchi, Y.; Crane, W.; Krausmann, F.; Eisenmenger, N.; Giljum, S.; Hennicke, P.; et al. Decoupling Natural Resource Use and Environmental Impacts from Economic Growth; A Report of the Working Group on Decoupling to the International Resource Panel; United Nations Environment Program: Nairobi, Kenya, 2011; p. 2.

2. Rockström, J. A safe operating space for humanity. Nature 2009, 461, 461-472.

3. Münz, R.; Reiterer, A.F. Overcrowded World? Population Explosion and International Migration, 1st ed.; Haus Publishing: London, UK, 2009; p. 324. 
4. Bringezu, S.; Schütz, H.; Pengue, W.; O’Brien, M.; Garcia, F.; Sims, R.; Howarth, R.; Kauppi, L.; Swilling, M.; Herrick, J. Assessing Global Land Use: Balancing Consumption with Sustainable Supply; A Report of the Working Group on Land and Soils of the International Resource Panel; United Nations Environmental Program: Nairobi, Kenya, 2014.

5. Baedeker, C.; Bahn-Walkowiak, B.; Bleischwitz, R.; Kolberg, S.; Mont, O.; Stengel, O.; Stenbæk Hansen, M.; Welfens, M.J. Survey on Consumption Behavior and Its Driving Forces; European Environment Agency, European Topic Center on Resource and Waste Management: Copenhagen, Denmark, 2008.

6. Welfens, M.J.; Liedtke, C.; Nordmann, J. Sustainable consumption: Between unsustainable reality and people's willingsness to act. In Proceedings of the Knowledge Collaboration \& Learning for Sustainable Innovation ERSCP-EMSU Conference, Delft, The Netherlands, 25-29 October 2010.

7. Lettenmeier, M.; Rohn, H.; Liedtke, C.; Schmidt-Bleek, F. Resource Productivity in 7 Steps. How to Develop Eco-Innovative Products and Services and Improve their Material Footprint; Wuppertal Spezial No. 41; Wuppertal Institute for Climate, Environment and Energy: Wuppertal, Germany, 2009.

8. Bringezu, S.; van de Sand, I.; Schütz, H.; Bleischwitz, R.; Moll, S. Analyzing global resource use of national and regional economies across various levels. In Sustainable Resource ManagementTrends, Visions and Policies; Bringezu, S., Bleischwitz, R., Eds.; Greenleaf Publishing: Sheffield, UK, 2009; pp. 10-51.

9. Lettenmeier, M.; Liedtke, C.; Rohn, H. A production- and consumption-oriented reference framework for low resource household consumption-Perspective for sustainable transformation processes of lifestyles. Resources 2014, 3, 488-515.

10. German Federal Ministry of Education and Research (BMBF). Bundesbericht Forschung und Innovation 2012; Bundesministerium für Bildung und Forschung BMBF: Bonn, Germany, 2012.

11. Wissenschaftlicher Beirat der Bundesregierung Globale Umweltveränderungen (WBGU). Welt im Wandel: Gesellschaftsvertrag für eine große Transformation; WBGU: Berlin, Germany, 2011.

12. Liedtke, C.; Welfens, M.J.; Rohn, H.; Nordmann, J. LIVING LAB: User-driven innovation for sustainability. Int. J. Sustain. High. Educ. 2012, 13, 106-118.

13. Liedtke, C.; Baedeker, C.; von Geibler, J.; Hasselkuß, M. User-integrated Innovation: Sustainable LivingLabs. In Proceedings of the 2nd PERL (Partnership for Education and Research about Responsible Living) International Conference Beyond Consumption-Pathways to Responsible Living, Berlin, Germany, 19-20 March 2012; Fricke, V., Schrader, U., Thoresen, V.W., Eds.; Technical University Berlin: Berlin, Germany, 2012; pp. 203-219.

14. Spaargaren, G.; Martens, S.; Beckers, T.A.M. Sustainable Technologies and Everyday Life. In User Behavior and Technology Development: Shaping Sustainable Relations between Consumers and Technologies; Verbeek, P.-P., Slob, A., Eds.; Springer: Dordrecht, The Netherlands, 2006; pp. 107-118.

15. Schrader, U.; Belz, F.-M. Involving users in sustainability innovations. In The Nature of Sustainable Consumption and How to Achieve it: Results from the Focal Topic "From Knowledge to Action-New Paths towards Sustainable Consumption; Defila, R., di Guilio, A., Kaufmann-Hayoz, R., Eds.; Oekom: München, Germany, 2012; pp. 335-350. 
16. Foekema, H.; van Thiel, L.; Lettinga, B. Watergebruik thuis 2007; TNS NIPO: Amsterdam, The Netherlands, 2008.

17. Wood, G.; Newborough, M. Dynamic energy-consumption indicators for domestic appliances: Environment, behavior and design. Energy Build. 2003, 35, 821-841.

18. Jackson, T. Motivating Sustainable Consumption: A Review of Evidence on Consumer Behavior and Behavioral Change; Policy Studies Institute: London, UK, 2005.

19. Talwar, S.; Wiek, A.; Robinson, J. User engagement in sustainability research. Sci. Public Policy 2011, 38, 379-390.

20. Pierson, J.; Lievens, B. Configuring Living Labs for a "Thick" Understanding of Innovation. Ethnogr. Prax. Ind. Conf. Proc. 2005, 1, 114-127.

21. Walther, G. Nachhaltige Wertschöpfungsnetzwerke. Überbetriebliche Planung und Steuerung von Stoffströmen entlang des Produktlebenszyklus; Gabler: Wiesbaden, Germany, 2010; p. 21.

22. Defila, R.; Di Giulio, A.; Kaufmann-Hayoz, R.; Winkelmann, M. Eine Forschungslandschaft zu Nachhaltigkeit im Konsum. In Wesen und Wege nachhaltigen Konsums. Ergebnisse aus dem Themenschwerpunkt "Vom Wissen zum Handeln-Neue Wege zum Nachhaltigen Konsum"; Defila, R., di Guilio, A., Kaufmann-Hayoz, R., Eds.; Oekom Verlag: München, Germany, 2011; pp. 23-46.

23. Zweck, A.; Bachmann, G.; Luther, W.; Ploetz, C. Nanotechnology in Germany: From forecasting to technological assessment to sustainability studies. J. Clean. Prod. 2008, 16, 977-987.

24. Von Geibler, J.; Rohn, H.; Schnabel, F.; Meier, J.; Wiesen, K.; Ziema, F.; Pastewski, N.; Lettenmeier, M. Ressourceneffizienzatlas. Eine internationale Perspektive auf Technologien und Produkte mit Ressourceneffizienzpotenzial. Available online: http://epub.wupperinst.org/ frontdoor/index/index/docId/3902 (accessed on 8 September 2014).

25. Rohn, H.; Pastewski, N.; Lettenmeier, M. Technologien, Produkte und Strategien-Ergebnisse der Potenzialanalysen. Ressourceneffizienz Paper 1.5; Wuppertal Institute: Wuppertal, Germany, 2010.

26. Kotakorpi, E.; Lähteenoja, S.; Lettenmeier, M. Households MIPS. Natural Resource Consumption of Finnish Households and Its Reduction; Ministry of the Environment: Helsinki, Finland, 2008.

27. Acosta-Fernández, J. Identifikation prioritärer Handlungsfelder für die Erhöhung der gesamtwirtschaftlichen Ressourcenproduktivität in Deutschland. Project Report from the BMBF Project "Steigerung der Ressourcenproduktivität als Kernstrategie einer nachhaltigen Entwicklung"; Wuppertal Institute for Climate, Environment and Energy: Wuppertal, Germany, 2007.

28. Rohn, H.; Lang-Koetz, C.; Pastewski, N.; Lettenmeier, M. Identifikation von Technologien, Produkten und Strategien mit hohem Ressourceneffizienzpotenzial-Ergebnisse eines kooperativen Auswahlprozesses. Arbeitspapier zu Arbeitspaket 1 des Projekts "Materialeffizienz und Ressourcenschonung” (MaRess). Ressourceneffizienzpaper 1.2.; Wuppertal Institute: Wuppertal, Germany, 2009.

29. Workshop "Sustainability potentials of Living Labs", Fraunhofer-inHaus-Zentrum, Duisburg, Germany, 20 April 2012.

30. Workshop "Living Labs for Sustainable Development-Perspectives", Projekt Zentrum Berlin, Germany, 4 July 2012.

31. SUS LAB Homepage. Available online: http://www.suslabnwe.eu (accessed on 22 August 2014).

32. Effizienzhaus Plus: Jahresbilanz. Bundesministerium für Verkehr und digitale Infrastruktur. Available online: http://www.bmvbs.de/DE/EffizienzhausPlus/effizienzhaus-plus_node.html (accessed on 22 August 2014). 
33. Intelligent Room and Building Systems. Available online: http://www.inhaus.fraunhofer.de (accessed on 7 September 2014).

34. Future Energy Center: achieving sustainability with innovative IT. Available online: http://global.sap.com/corporate-en/innovation/living-labs/future-energy-center.epx (accessed on 22 August 2014).

35. Liedtke, C.; Baedeker, C.; Rohn, H.; Hasselkuß, M. Sustainable LivingLabs-European Research Infrastructure for the user-integrated development of sustainable product and service innovation (SusLabNWE). In Proceedings of the 6th International Conference on Indicators and Concepts of Innovation (ICICI), Friedrichshafen, Germany, 22-23 November 2012.

36. Liedtke, C.; Baedeker, C.; Hasselkuß, M.; Rohn, H.; Grinewitschus, V. User-integrated Innovation in Sustainable LivingLabs: An experimental infrastructure for research and development of Sustainable Product-Service-Systems. J. Cleaner Prod. 2014, in press.

37. Von Geibler, J.; Baedeker, C.; Hasselkuß, M.; Jordan, N.D.; Liedtke, C.; Rohn, H. Living labs as a reflexive user-driven research infrastructure to promote sustainable consumption and production patterns: Experiences from exploratory research. In Proceedings of the 18th Annual International Sustainable Development Research Conference, University of Hull, Hull, UK, 24-26 June 2012.

38. Liedtke, C.; Von Geibler, J.; Baedeker, C. The "sustainability living lab" as a reflexive user-integrating research infrastructure. In Proceedings of the 3rd International Conference on Sustainability Transitions, Lyngby, Denmark, 29-31 August 2012; Danmarks Tekniske Universitet: Lyngby, 2012; pp. 206-211. Available online: http://www.ist2012.dk/custom/files/ist2012/ Fullpapers/Esessions-fullpapers.pdf (accessed on 14 May 2013).

39. Wuppertal Institute. Informationen zur europäischen Living Lab-Infrastruktur in "SusLabNWE"Errichtung einer vernetzten Infrastruktur für nutzerintegrierte Nachhaltigkeitsinnovationen. Available online: http://wupperinst.org/projekte/details/wi/p/s/pd/381/ (accessed on 8 September 2014).

40. Peters, A.; Sonnberger, M.; Dutschke, E.; Deuschle, J. Theoretical Perspective on Rebound Effects from a Social Science Point of View-Working Paper to Prepare Empirical Psychological and Sociological Studies in the REBOUND Project; In Working Paper Sustainability and Innovation; Fraunhofer ISI: Karlsruhe, Germany, 2012. Available online: http://www.isi.fraunhofer.de/isi-wAssets/docs/e-x/working-papers-sustainability-and-innovation/ WP02-2012_Rebound_psychological_sociological_background.pdf (accessed on 8 September 2014).

41. Santarius, T. Der Rebound-Effekt: Über die unerwünschten Folgen der erwünschten Energieeffizienz. In Impulse zur Wachstumswende 5; Wuppertal Institut: Wuppertal, Germany, 2012.

42. Jackson, T. Prosperity without Growth? The Transition to a Sustainable Economy; Sustainable Development Commission: London, UK, 2009.

43. Sorrell, S. The Rebound Effect: An Assessment of the Evidence for Economy-Wide Energy Savings from Improved Energy Efficiency; UK Energy Research Center: London, UK, 2007.

44. Hausschildt, J.; Gemünden, H.G. Promotoren-Champions der Innovation, 2nd ed.; Gabler: Wiesbaden, Germany, 1999; p. 311.

45. Spangenberg, J.H.; Femia, H.; Hinterberger, F.; Schütz, H. Material Flow-based Indicators in Environmental Accounting; Office for Official Publications of the European Communities: Luxembourg, 1999.

46. Lin, I.-H.; Chang, O.H.; Chang, C. Importance of Sustainability Performance Indicators as Perceived by the Users and Preparers. J. Manag. Sustain. 2014, 4, 34-45.

47. Saurat, M.; Ritthoff, M. Calculating MIPS 2.0. Resources 2013, 2, 581-607. 
48. Wiesen, K.; Teubler, J.; Rohn, H. Resource Use of Wind Farms in the German North Sea. The Example of Alpha Ventus and Bard Offshore I. Resources 2013, 2, 504-516.

49. Fichter, K. Modelle der Nutzerintegration in den Innovationsprozess: Möglichkeiten und Grenzen der Integration von Verbrauchern in Innovationsprozesse für nachhaltige Produkte und Produktnutzungen in der Internetökonomie; WerkstattBerichte/IZT, Institut für Zukunftsstudien und Technologiebewertung: Berlin, Germany, 2005; No. 75.

50. Kristof, K. Models of Change. Einführung und Verbreitung Sozialer Innovationen und gesellschaftlicher Veränderungen in transdisziplinärer Perspektive; vdf Hochschulverlag: Zürich, Switzerland, 2010; p. 584.

51. Bliesner, A.; Rohn, H. Kompetenzentwicklung zur Initiierung und Umsetzung einer RessourcenKultur. In RessourcenKultur: Vertrauenskulturen und Innovationen für Ressourceneffizienz im Spannungsfeld normativer Orientierung und betrieblicher Praxis; Klinke, S., Rohn, H., Eds.; Nomos: Baden-Baden, Germany, 2012.

52. Eckpunkte eines ökologisch tragfähigen Wohlfahrtskonzepts 2013. Gesellschaft für Wirtschaftliche Strukturforschung $\mathrm{mbH}$. Available online: http://www.gws-os.com/de/content/ blogcategory/72/255/ (accessed on 22 August 2014).

53. myEcoCost Homepage. Available online: http://www.myecocost.eu (accessed on 22 August 2014).

54. UBA Ausschreibung U667 UFOPLAN 371317103 Erfolgsbedingungen für Systemsprünge und Leitbilder einer ressourcenleichtem Gesellschaft. Available online: http://www.umweltbundesamt.de/ service/ausschreibungen/vergabeunterlagen-ufo.php (accessed on 20 April 2013).

55. Sozial-ökologische Forschung (SÖF). Available online: http://www.sozial-oekologischeforschung.org (accessed on 22 August 2014).

56. Bundesministerium für Bildung und Forschung (BMBF). Bekanntmachung von Richtlinien zur Förderung von Forschung und Entwicklung auf dem Gebiet "Technik stellt sich auf den Menschen ein-Innovative Schnittstellen zwischen Mensch und Technik”; BMBF, Bundesanzeiger (BAnz AT 19.12.2012 B9): Bonn, Germany, 2012.

57. BilRess: Education for resource conservation and resource efficiency. Available online: http://wupperinst.org/uploads/tx_wupperinst/BilRess_Flyer_en.pdf(accessed on 8 September 2014).

58. Bliesner, A.; Liedtke, C.; Rohn, H. Change Agents für Nachhaltigkeit: Was müssen sie können? Z. Führung Organ. 2012, 82, 49-53.

59. Stengel, O.; Liedtke, C.; Baedeker, C.; Welfens, M.J. Theorie und Praxis eines Bildungskonzepts für eine nachhaltige Entwicklung. Umweltpsychologie 2008, 12, 29-42.

60. INNOCENTIVE Homepage. Available online: https://www.innocentive.com/ (accessed on 22 August 2014).

(C) 2014 by the authors; licensee MDPI, Basel, Switzerland. This article is an open access article distributed under the terms and conditions of the Creative Commons Attribution license (http://creativecommons.org/licenses/by/3.0/). 